\title{
Contexto, Conhecimento Enciclopédico e a Construção de Inferências Metonímicas e Metafóricas
}

\author{
Context and Encyclopedic Knowledge and the \\ Construction of Metonymic and Metaphorical Inferences
}

\author{
Mara Sophia Zanotto \\ Dieli Vesaro Palma
}

Pontifícia Universidade Católica de São Paulo - PUC-SP - São Paulo - São Paulo - Brasil

\begin{abstract}
Resumo: Este artigo faz parte do projeto de pesquisa que tem por objetivo central investigar empiricamente o que a metáfora realmente significa para leitores reais. $\mathrm{A}$ investigação tem sido realizada com metodologia interpretativista, tendo como método principal o Pensar Alto em Grupo, que é uma prática dialógica vivenciada por vários grupos de leitores, constituindo, assim, um estudo de caso coletivo. Nos dois estudos de caso realizados, ocorreu uma complexa interação de inferências metonímicas e metafóricas na construção das leituras. Desse achado emergiram novas questões de pesquisa, que serão focalizadas neste trabalho: "Qual o papel dos contextos evocados e dos conhecimentos ativados pelos leitores na construção das inferências metonímicas e metafóricas?"; e "Qual o papel da metonímia conceptual na construção dos sentidos?" Para responder a essas questões, foram analisados e discutidos os dados de um grupo do segundo estudo de caso.
\end{abstract}

Palavras-chave: Contexto. Frame. Inferência. Metáfora. Metonímia.

\begin{abstract}
This article is a part of the research project whose main objective consists in investigating on an empirical basis what metaphor actually means to real readers. This empirical research has been carried out with interpretive methodology. Its main method is Group Think-Aloud, which is a dialogical practice experienced by several groups of readers reading the same text, thus constituting a collective case study. In both case studies conducted, there was a complex interaction between metonymical and metaphorical inferences in meaning construction. Through this finding, further questions emerged, which will be focused in this paper: "What is the role played by the contexts evoked and the knowledge activated by readers in constructing metonymic and metaphorical inferences?"; "What is the role played by conceptual metonymy in the process of meaning construction?" In order to answer these questions, data of one group of the second case study were analysed and discussed.
\end{abstract}

Keywords: Context. Frame. Inference. Metaphor. Metonymy. 


\section{Introdução}

Este artigo faz parte do projeto de pesquisa que tem por objetivo central investigar empiricamente - que a metáfora realmente significa para leitores reais, de modo a contribuir para elucidar a complexidade da significação da metáfora em uso. Essa investigação empírica tem produzido evidências dos processos sociocognitivos e culturais envolvidos no raciocínio inferencial realizado pelos leitores na construção das múltiplas leituras de metáforas (que constituem os produtos), possibilitando uma discussão da significação da metáfora na interface entre os processos e os produtos. Esperamos que essa interface possibilite a discussão posterior da relevância das leituras com base na coerência construtiva evidenciada pelos processos.

Para realizar a investigação, foi necessário construir um desenho metodológico (ZANOTTO, 2014) adequado aos objetivos da pesquisa, tendo como método principal o Pensar Alto em Grupo (ZANOTTO, 1995), que é vivenciado por vários grupos de leitores lendo o mesmo texto, constituindo, assim, um estudo de caso coletivo (STAKE, 1998). O Pensar Alto em Grupo, por ser uma prática dialógica e colaborativa (BAKHTIN, 2003), propicia condições favoráveis para os leitores resolverem as incongruências da metáfora e da metonímia, possibilitando, desse modo, a elicitação espontânea de raciocínios inferenciais na interpretação dessas figuras.

Nos dois estudos de caso realizados, ocorreu uma complexa interação de processos inferenciais metonímicos e metafóricos na compreensão da linguagem figurada, porém com uma diferença importante: a) no primeiro, a interação representou uma metaftonímia integrada (GOOSSENS, 2003), devido ao fato de os dois tipos de inferências atuarem na construção de uma mesma leitura (ZANOTTO; PALMA, 2008; MOURA; ZANOTTO, 2009); e, no segundo, ocorreu uma metaftonímia cumulativa (GOOSSENS, 2003), porque as inferências metonímicas e metafóricas atuaram na construção de leituras diferentes (ZANOTTO, 2010). Dessa constatação emergiram novas questões:

a) Qual o papel dos contextos evocados e dos conhecimentos ativados pelos leitores na construção das inferências metonímicas e metafóricas?

b) Qual 0 papel da metonímia conceptual na construção dos sentidos?

Neste artigo, vamos retomar os dados de Zanotto (2010), os quais revelaram a construção de uma cadeia de inferências metonímicas, que possibilitou a construção de uma inferência metafórica, constituindo, desse modo, uma metaftonímia cumulativa. Como a análise de dados qualitativos é um processo que exige diferentes etapas 'para ir cada vez mais fundo no processo de compreensão dos dados' (CRESWELL, 2010, p. 217), nossa proposta inicial para aprofundar a interpretação desses dados foi analisar os contextos evocados pelos leitores e os conhecimentos enciclopédicos ativados e verificar de que modo eles atuaram na construção das inferências metonímicas e metafóricas. No entanto, a análise nos surpreendeu e nos ofereceu dados relevantes para discutir o papel da metonímia conceptual em diferentes processos inferenciais, e esse fato nos levou a criar e discutir também a segunda pergunta.

A complexidade da interação de processos inferenciais metonímicos e metafóricos, que ocorreu nos dois estudos de caso, nos levou a procurar teorias que pudessem explicar esse fenômeno. Assim, ao buscar teóricos que discutissem a interação entre a metáfora e a metonímia, encontramos autores com ideias relevantes para a nossa pesquisa na área de construção dos sentidos, que passamos a apresentar.

\section{Metonímia na área de construção de sentidos}

A área da construção de sentidos parte do pressuposto "aceito de maneira unânime na Linguística Cognitiva de que o significado não reside 
nas unidades linguísticas, mas é construído nas mentes dos usuários da língua" (RADDEN et al., 2007 , p. 1). Isso significa que, para o falante, as unidades linguísticas funcionam como 'pistas' para construir, por meio de processos inferenciais, uma representação conceptual com sentido.

Para Radden et al. (2007), o uso da língua se caracteriza pela 'subespecificação', ou seja, não dizemos tudo o que seria necessário para uma interpretação completa. Para esses autores a 'subespecificação' se divide em três tipos: “(i) as unidades linguísticas verbalizam sentidos implícita ou indiretamente, (ii) as unidades linguísticas são indeterminadas, e (iii) as unidades linguísticas são incompatíveis" (RADDEN et al., 2007, p. 5). Por questão de espaço, vamos nos deter no terceiro tipo, por ser a condição necessária das figuras, segundo Cameron (2003). No entanto, Cameron denomina esse fenômeno de incongruências e propõe a distinção de dois tipos: a incongruência semântica, que consiste num conflito entre partes de um enunciado, e a pragmática, que se caracteriza por um conflito do enunciado em relação ao contexto.

As incongruências, ou incompatibilidades, ocorrem no texto literário de forma mais perceptível e, em geral, associadas a lacunas, causando, muitas vezes, desautomatização da leitura e um esforço cognitivo maior para sua interpretação. Elas também ocorrem na oralidade, mas, pelo fato de serem convencionais, não temos consciência delas.

Devido à 'subespecificação', Radden et al. (2007, p. 3) afirmam que o que dizemos é apenas um 'pedaço' do que queremos dizer e, para sermos entendidos, nosso interlocutor terá que evocar muitos conhecimentos e contextos. Esses autores se apoiam em Fauconnier (1999), cuja metáfora do iceberg explica de forma iluminadora o que ocorre na comunicação:

A linguagem é apenas a ponta de um espetacular iceberg cognitivo, e quando nos envolvemos em qualquer atividade linguística, seja ela comum ou artisticamente criativa, recorremos inconscientemente a vastos recursos cognitivos, evocamos inumeráveis modelos e frames, construímos incontáveis conexões, coordenamos ampla variedade de informações, e nos envolvemos em mapeamentos criativos, transferências e elaborações. É disso que a linguagem trata e é para isso que a linguagem serve (FAUCONNIER, 1999, p. 96).

Como a construção de sentidos constitui um processo inferencial para interpretar os diferentes tipos de subespecificação, pode-se dizer que para descobrir outros aspectos do iceberg, precisaremos construir incontáveis inferências, com base em fatores contextuais, conhecimentos, frames e princípios pragmáticos (entre eles o Princípio da Relevância). Além desses fatores, Barcelona (2007) trabalha com a hipótese de que a metonímia conceptual frequentemente guia os processos inferenciais. Radden et al. (2007, p. 11) observam também que "a metonímia é sem dúvida um poderoso princípio que guia os processos inferenciais de construção de sentidos".

Com o método que temos utilizado, a prática dialógica de Pensar Alto em Grupo, foi possível obter evidência de processos inferenciais metonímicos e metafóricos, muitas vezes organizados em cadeias. Dois estudiosos, Barcelona (2007) e Hilpert (2007) apontaram que muitas inferências constituem cadeias inferenciais por processamentos metonímicos. Essas cadeias têm sido estudadas na lexicalização e na gramaticalização (HILPERT, 2007) e, com menos frequência, na interpretação de textos por leitores reais. Barcelona (2007) constitui uma exceção, pois ele analisa seus próprios processos inferenciais na leitura de um texto autêntico.

$\mathrm{Na}$ pesquisa que estamos desenvolvendo, 0 método utilizado tem possibilitado a elicitação dos conhecimentos do leitor, dos contextos evocados, assim como dos processos inferenciais para resolver as incongruências e as lacunas de um texto poético, gerando dados relevantes para discutir as questões de pesquisa. Por essa razão a análise irá focalizar a interação entre os conhecimentos enciclopédicos ativados, os contextos evocados e a construção das inferências metonímicas e metafóricas, assim como os papéis da metonímia conceptual na construção dos sentidos.

Após esta breve discussão teórica, devido às limitações de espaço, passamos a apresentar a 
metodologia, e, em seguida, a análise de dados e as considerações finais.

\section{Metodologia}

A pesquisa tem sido desenvolvida com metodologia interpretativista (ERICKSON, 1986), na área da linguística aplicada. O interpretativismo se caracteriza principalmente por ter a preocupação de ouvir as vozes dos participantes das práticas sociais investigadas e de construir colaborativamente conhecimento útil para os participantes.

O método principal é o Pensar Alto em Grupo (ZANOTTO, 1995), que é resultado de uma adaptação do protocolo verbal (ERICSSON; SIMON, 1984/1993). O protocolo verbal se caracteriza por ser uma atividade monológica, pois o 'informante' pensa alto enquanto executa uma tarefa diante do pesquisador, que o observa e não pode responder para não interferir no pensamento do 'informante'. Já - Pensar Alto em Grupo representa uma mudança paradigmática em relação ao protocolo verbal, por ser afinado com a epistemologia do dialogismo (BAKHTIN, 2003). Ele é, portanto, um método de pesquisa orientado por uma concepção dialógica de leitura, e, por isso, oferece condições para os leitores interpretarem livremente um texto literário, propiciando, desse modo, a elicitação espontânea de inferências metonímicas e metafóricas, que não são apreendidas nos experimentos (GIBBS, 2007).

Como o leitor constrói as leituras com base nas suas experiências e conhecimentos, é natural que ocorram múltiplas leituras. Desse modo, para investigar a variação de leituras, o Pensar Alto em Grupo é vivenciado por vários grupos de leitores (de 4 a 6) lendo o mesmo texto, constituindo assim um estudo de caso coletivo (STAKE, 1998; ZANOTTO, 2014).

Os dados analisados neste artigo fazem parte do segundo estudo de caso, que teve como objeto de leitura a poesia "A Montanha Pulverizada", de Drummond de Andrade. Esse estudo de caso é constituído por cinco grupos de leitores. Escolhemos os dados do grupo 2 para análise, pelo fato de esse grupo ter construído uma leitura relevante que não ocorreu nos outros grupos.

A poesia fez parte da prova do Exame Nacional do Ensino Médio (ENEM) de 2006, porém com as 3 estrofes iniciais suprimidas. Primeiramente, foi entregue aos alunos a poesia como apareceu na prova, mas sem a folha da prova. Depois dessa leitura em grupo, foi entregue aos alunos a folha da prova, para, em seguida, mostrar a poesia inteira (Anexo A). Neste trabalho, serão considerados apenas os dados da leitura da estrofe que constou da prova:

\section{A montanha pulverizada \\ Esta manhã acordo e não a encontro. \\ Britada em bilhões de lascas deslizando em correia transportadora entupindo 150 vagões \\ no trem-monstro de 5 locomotivas - o trem maior do mundo, tomem nota - foge minha serra, vai \\ deixando no meu corpo a paisagem mísero pó de ferro, e este não passa.}

Carlos Drummond de Andrade (2000) ${ }^{1}$ Antologia Poética. Rio de Janeiro: Record.

Os participantes, cujas vozes serão analisadas neste artigo, eram alunos de um Programa de PósGraduação e cursavam uma disciplina voltada para questões de letramento. Eles mesmos escolheram seus nomes fictícios: Fernanda, Sosô, Sócrates, Asdrúbal, Eulália, Juliana e Nete. Quanto à profissão, quatro eram professores da rede pública (Ensino Fundamental e Médio), dois da rede privada (Ensino Superior) e uma era fonoaudióloga.

\section{Análise de dados}

Alguns excertos da transcrição do Pensar Alto em Grupo vivenciado por esse grupo de alunos foram

\footnotetext{
${ }^{1}$ A referência que consta na prova não está correta, pois nessa antologia não figura a poesia (ver referências corretas no poema no Anexo A). Além disso, há um erro no penúltimo verso da última estrofe: ao invés de 'deixando no meu corpo a paisagem', verificamos em várias edições, desde a primeira, que o original é 'deixando no meu corpo e na paisagem'. No entanto, a forma errada criou mais uma incongruência, que os alunos conseguiram resolver de forma belíssima num raciocínio coletivo. Afinal, esse tipo de incongruência é um traço marcante do estilo de Drummond, que propõe enigmas para o leitor resolver.
} 
analisados em Zanotto (2010). Esse artigo focalizou os excertos que constituíram o ápice da construção de sentidos dos versos finais, que apresentam as incongruências mais desafiantes.

No entanto, os turnos anteriores a esse momento produtivo da atividade constituíram uma preparação importante para a elaborada interpretação dos versos finais. Veremos, na primeira parte da análise, em que consistiu essa preparação, ou seja, que conhecimentos enciclopédicos e contextos foram evocados ou construídos. $\mathrm{Na}$ segunda parte da análise, serão retomados de forma breve os dados de Zanotto (2010), para discutir como os contextos e conhecimentos evocados atuaram na construção das inferências metonímicas e metafóricas dos três versos finais. Discutiremos também os papéis da metonímia na construção de inferências nas duas partes.

\subsection{Evocando contextos e conhecimentos}

Antes de iniciar a análise, é importante contextualizar o evento de leitura para o leitor: a vivência do Pensar Alto em Grupo, que será foco da análise, se deu na última aula do semestre de uma disciplina voltada para questões de letramento. Logo no início da vivência, a professora comenta que três alunos já haviam lido esse texto numa vivência em outra disciplina. Os três eram: Asdrúbal, Eulália e Nete. Devido a esse fato, a professora resolveu dar voz primeiramente aos que desconheciam o texto.

Assim, no excerto 1 a seguir, Juliana começa dizendo que seu 'metaforômetro' estava desligado, pois não havia percebido nenhuma metáfora e tinha achado o texto muito simples. Embora a professora pesquisadora não tivesse falado em metáfora quando propôs a leitura, Juliana sabia que a professora pesquisava 'a metáfora', daí ter afirmado que não havia percebido nenhuma metáfora. A professora falou então a Juliana que não precisava se preocupar com essa figura, pois de fato não pretendemos que o aluno identifique a metáfora ou fique preocupado em analisá-la, mas sim em interpretar o texto. Embora tivesse achado inicialmente o texto simples, no turno final desse excerto, Juliana acaba reconhecendo que 'o finzinho tá mais embolado'. De fato os três últimos versos apresentam mais incongruências (representadas por barras), devido à personificação da montanha, que a torna um agente das ações de fugir e deixar a paisagem no corpo do poeta:

Foge / minha serra, / vai Deixando/ no meu corpo / a paisagem/ mísero pó de ferro,/ e este não passa.

\section{Excerto 1 - Finzinho embolado}

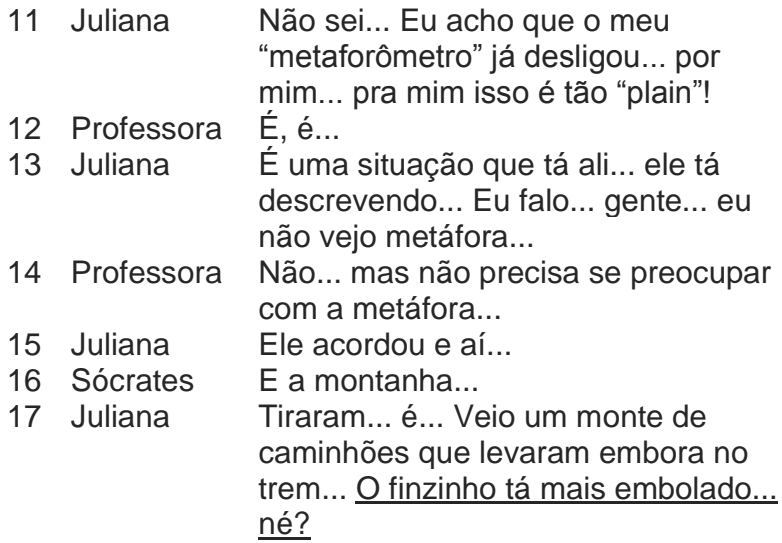

Logo em seguida, no excerto 2, Sócrates começa a relacionar o texto com o contexto de Minas Gerais, que era 'a terra dele', ou seja, a terra de Drummond. Assim ele e Asdrúbal vão interagir para construir o contexto situacional a que se refere a poesia e que é essencial para sua compreensão:

\section{Excerto 2 - Contexto situacional - Itabira, Minas Gerais $^{2}$}

24 Sócrates

Esse texto do Drummond tinha muito essa ligação com a terra dele... (barulho de papel batendo na mesa) tinha poesia que falava da terra do ferro... as montanhas... da região das...

25 (?) Minas Gerais...

26 Sócrates Minas Gerais...

27 Asdrubal Itabira...

28 Professora É... porque ele fala do ferro aí... né?

29 Sócrates Fala..

30 Professora O mísero pó de ferro... acho que é o único lugar... né?

31 Nete Quando ele diz pulverizada... no título... Eu visualizei uma montanha infestada de pó de ferro....como se tivesse pulverizado essa montanha... 32 Sócrates Não... eu vi como destruída mesmo..

2 As palavras da poesia mencionadas pelos alunos nos excertos serão representadas por itálico. Os grifos representam as palavras-chave da análise. 
33 Nete

34 Sócrates

35 Nete

\begin{abstract}
Aí virou pó...
É... virou pó...

No decorrer da leitura ele fala que ela foi britada em bilhões de lascas... né? Aí...e o que sobrou é o pó de ferro, e este não passa... chama a atenção quando ele fala que é... trem-monstro de cinco locomotivas - trem maior do mundo, tomem nota dá a impressão de que ele chama a atenção pra que... pelo fato de isso aqui se tornar algo histórico.
\end{abstract}

Sócrates inicia o excerto 2 dizendo que o texto tem ligação com a terra do autor, mencionando duas características importantes: "da terra do ferro... e das montanhas", e, logo após dizer 'da região das...', faz uma pausa, quando um colega (não identificado) completa sua ideia, dizendo 'Minas Gerais'. Asdrúbal, por sua vez, especifica a cidade: 'Itabira', completando a ideia de Sócrates, que, ao fazer a pausa, deu a entender que não se lembrava do nome da cidade em que Drummond nasceu e viveu por um tempo. A professora concorda com Sócrates e diz que o poeta fala do ferro só no verso final da poesia. Desse modo duas características: 'o ferro' e 'as montanhas' possibilitaram a inferência do lugar: 'Itabira', constituindo, assim, uma inferência guiada pela metonímia conceptual PARTE PELO TODO. O 'ferro' e as 'montanhas' foram o pico do iceberg, pois possibilitaram inferir o contexto situacional de referência da poesia.

É importante observar que no outro grupo do qual Asdrúbal e Nete participaram, um colega lembrou a conhecida poesia de Drummond: Confidência do Itabirano, em que o poeta fala da influência do ferro em Itabira e na sua vida. Desse modo, Asdrúbal e Nete, embora não tenham falado explicitamente desse poema, tinham esse conhecimento que serviu de base para a construção do contexto situacional nessa vivência. E Sócrates, ao dizer que 'tinha poesia que falava da terra do ferro, das montanhas', provavelmente estaria se referindo a essa poesia por ser mais conhecida. Afirmo isso porque dos cinco grupos que constituem este estudo de caso coletivo, três mencionaram essa poesia e conseguiram inferir mais facilmente o contexto do que os outros dois grupos que não a conheciam. Daí a importância do conhecimento enciclopédico do contexto (ou um dos contextos) da vida do poeta. Muitos alunos desconhecem a presença e influência do ferro na vida de Itabira, e a primeira estrofe da poesia Confidência do Itabirano mostra com força poética o significado do ferro na vida do poeta e dos itabiranos:

\section{Confidência do Itabirano}

Alguns anos vivi em Itabira. principalmente nasci em Itabira. Por isso sou triste, orgulhoso: de ferro.

Noventa por cento de ferro nas calçadas.

Oitenta por cento de ferro nas almas.

E esse alheamento do que na vida é porosidade e comunicação.

Carlos Drummond de Andrade (1967, p. 101-102)

Depois de Sócrates e Asdrúbal terem identificado o contexto situacional da poesia, Nete conta a primeira impressão que teve quando leu, dizendo que visualizou 'uma montanha infestada de pó de ferro. Como se tivesse pulverizado essa montanha' (t. 31). Ela realizou assim a construção de uma hipótese de leitura por processamento descendente, que foi descartada por Sócrates: 'Não, eu vi como destruída mesmo' (t. 32). A afirmação de Sócrates chama a atenção para 0 fato de que 'pulverizada' é uma forma poética de dizer que a montanha foi destruída mesmo. Nete concorda com a ideia de Sócrates, dizendo: 'Aí virou pó' (t. 33). Sócrates expressa sua concordância com ela no turno 34. No turno 35, ela sintetiza o processo: a montanha 'foi britada em bilhões de lascas, né? Aí... e o que sobrou é o pó de ferro, e este não passa...'.

Assim, Nete relacionou de forma coerente três pistas do texto: a montanha pulverizada (no título), mísero pó de ferro, e este não passa (no verso final), e britada em bilhões de lascas (no terceiro verso da estrofe final), sendo que os dois primeiros, que são efeitos mais dramáticos da extração do minério, estão em lugares proeminentes da poesia. $O$ texto, portanto, enfatiza os efeitos da ação de extrair o ferro, que constituem pistas para o leitor inferir a ação que os provocou. A extração não está explícita na poesia, nem na fala dos alunos ainda, mas pressuposta na 
fala deles. Ela será explicitada no próximo excerto, no qual os alunos falarão em 'extração' de árvores.

Nete, no final do turno 35, focaliza o verso 'trem maior do mundo, tomem nota' e interpreta sua força ilocucionária, dizendo: 'dá a impressão de que ele chama a atenção pra que... é o fato de isso aqui se tornar algo histórico...', ou seja, é relevante o que está acontecendo, portanto, prestem atenção. Ela constrói, assim, uma inferência pragmática, guiada pela metonímia CAUSA PELO EFEITO, como propõem Panther e Thornburg (2003), que "foram um dos primeiros a reconhecer a função da metonímia nas inferências" (RADDEN et al., 2007, p. 10). Entretanto, a força ilocucionária desse 'tomem nota' será interpretada também como denúncia ${ }^{3}$, crítica $^{4}$ pelo grupo, evidenciando que se trata de indeterminação da força ilocucionária (ZANOTTO; MOURA, 2000).

No excerto 3, Asdrúbal inicia retomando a questão do 'trem maior do mundo' da fala de Nete (t.35). Nesse excerto, ficará mais explícita a ideia de extração que causa destruição, em contextos de desmatamento:

\section{Excerto 3 - Evocando contextos similares}

41 Asdrúbal O poema já pega a questão... bem hiperbólica... Quer dizer, um tremmonstro assim dá a ideia assim de grandeza... né? O tamanho do monstro... trem maior do mundo.

42 Professora É engraçado... Existe com muitas locomotivas?

43 (?) Eu já ouvi falar com duas... mas com muitas... nunca ouvi falar.

44 Sócrates Já exagera para levar a montanha toda... tem que ser um trem bem...

45 Asdrúbal Mas parece assim... o que dá a entender que esse fato foi tão assim... é... foi da noite pro dia... foi uma coisa assim muito rápida... né?

46 Sócrates Mas acho que a gente vê a paisagem, é... se esvaindo, sumindo... né? Fora que você abre o olho... você já perdeu tudo aquilo... já destruíram mesmo... ele (?)... carregar um pouquinho mais... levar pras florestas é o que acontece também... né?

\section{Professora Como é que é?}

\footnotetext{
${ }^{3}$ No turno 181, Asdrúbal fala: Fiquem atentos, não é uma coisa pra se perder. Não é aquele negócio, é... o que se fala não se escreve, entendeu? Tomem nota que isso é uma denúncia.

${ }^{4}$ No turno 182, Fernanda diz: eu acho que aqui é uma coisa muito grave quando ele coloca "trem maior do mundo, tomem nota", é uma crítica.
}

48 Sócrates

49 Juliana

50 Sócrates

$51 \quad$ Nete

Se a gente transportar esse... as montanhas pras florestas aí... a gente tá vendo da Amazônia principalmente... que destroem da noite pro dia...

Não precisa nem ser Amazônia... quando eu fui pra Franca no encontro do GEL do ano passado... a gente andando na estrada... o que você via... o que você via de galho no chão, galho... ( ) será que choveu? Porque aqui quando você vê galho no chão... é porque choveu... galho, galho, galho... ( ) pra lá nas estradas, mas... quilômetros de galhos. Aí mais pra frente a gente começou a ver os caminhões... eram uns caminhões imensos com aquelas... com aqueles troncos de madeira enorme... que sobra pedaço...então vai desgalhando no caminho, aí eles vão "semeando" os galhos... Aí ( ) então esse monte de galho é sinal de que as árvores foram extraídas na volta... que o tempo todo em algum lugar eles tão desmatando...

tão...

E a gente percebe assim, perto da minha ( )... Pra ir pra Guaxupé você passa, pega a Imigrantes tem um trecho ali que você olhava assim... Há pouco tempo, pouco tempo... Toda vez que eu passava... me admira... que... há pouco tempo você olhava e era tudo árvore... agora... casas... então daqui a pouco a serra toda tá virando... casas. E cê fica assim... como se fosse "acordei agora já tou vendo tudo transformado".

Então porque esse 'acordar' na verdade seria o despertar para isso...

Nos turnos 41 a 44, Asdrúbal, a professora e Sócrates refletem sobre o trem maior do mundo e Sócrates conclui que, para levar a montanha, tem que ser um trem bem grande. Chama a atenção deles o tamanho do trem, porque não se trata de algo que faça parte do conhecimento enciclopédico do grupo.

Em seguida, eles passam a discutir outro aspecto do texto que também apresenta incongruência para eles: 'Esta manhã acordo e não a encontro'. É Asdrúbal novamente que propõe a questão ao dizer: 'Mas parece assim... o que dá entender que esse fato foi tão assim... é... foi da noite pro dia... foi uma coisa assim muito rápida, né?' (t. 45).

De fato é muito estranho dizer Esta manhã acordo e/ não a encontro referindo-se a uma 
montanha. Há um problema de referenciação aqui, pois, apesar de o título ser A Montanha Pulverizada, que constituiria, por regra, o antecedente do 'não a encontro', os dois primeiros versos levam a supor que a montanha sumiu da noite para o dia. Sócrates tenta explicar que a paisagem vai 'se esvaindo, sumindo, né? Fora que você abre o olho....você já perdeu tudo aquilo... já destruíram mesmo..." (turno 46). A ideia de que a montanha sumiu da noite para o dia foi resultado de uma inferência metonímica de EFEITO PELA CAUSA, ou seja, o 'acordo e não a encontro' seria o efeito provocado pelo fato de a montanha ter sumido de algum modo.

Sócrates termina o turno 46 dizendo: 'levar pras florestas é o que acontece também, né?' Mas a professora não entende o que ele quis dizer e pergunta: como é que é? No turno 48, ele esclarece o que quis dizer com "levar pras florestas...": Se a gente transportar esse... as montanhas pras florestas aí, a gente tá vendo da Amazônia principalmente... que destroem da noite pro dia. Em outras palavras, Sócrates quis dizer que poderia transportar para outro contexto: o do desmatamento, que também tem como efeito a destruição. Em seguida, Juliana diz que não é preciso pensar na Amazônia, mas no próprio estado de São Paulo acontece isso. Ela dá o exemplo de uma viagem (para participar de um Seminário do Grupo de Estudos Linguísticos (GEL), na cidade de Franca), na qual viu sinais de desmatamento na estrada, ou seja, inúmeros galhos na estrada derrubados por caminhões que carregavam troncos de 'árvores extraídas' da região. Eles estão, portanto, lembrando contextos mais familiares em que ocorre a 'extração' de árvores e a destruição. Sócrates, por sua vez, lembra outro contexto familiar se referindo a uma viagem para uma cidade de Minas, Guaxupé, em que constatou também desmatamento nas montanhas da Rodovia dos Imigrantes (São PauloSantos) para a construção de casas. Ele termina o turno 50 dizendo: me admira... que... há pouco tempo você olhava e era tudo árvore... agora... casas... então daqui a pouco a serra toda tá virando... casas. E cê fica assim... como se fosse "acordei agora já tou vendo tudo transformado". O final de sua fala dá a deixa para Nete concluir: Então porque esse 'acordar' na verdade seria o despertar para isso...

Esses contextos mais familiares e similares, em que ocorre outra forma de 'extração', contribuem para facilitar a compreensão do não familiar, ou seja, a 'extração do minério de ferro', que vai constituir um dos frames para a interpretação do 'mísero pó de ferro, e este não passa'. Eles estão evocando contextos em que ocorre outra forma de extração, mas que também destrói o meio ambiente como o da Montanha Pulverizada. Dessa forma o frame da EXTRAÇÃO (DE MINÉRIO OU VEGETAL) leva à destruição, ou a outro frame: CAUSAR DANO. Os dois frames, que estão ligados pela metonímia conceptual EFEITO PELA CAUSA, funcionarão como guia inferencial para os alunos construírem interpretações mais específicas dos versos finais.

Nete acaba voltando à questão do 'acordo e não a encontro' e a soluciona dizendo: Talvez a metáfora... você falou que não tem... esteja aí. nessa hipérbole... (...)... e também fala assim "acordo e não encontro", é que ele se deu conta naquele dia... não é que foi do dia pra noite [Sic ] (t. 53).

No excerto 4, a professora retoma a ideia de Nete sobre o 'acordo e não encontro' (t. 58), leva a discussão para a questão do 'trem-monstro' (t. 60) e acaba observando que o trem precisa ser muito grande porque 'se é pra puxar ferro, é muito pesado, né? (t. 62). A menção ao peso do ferro dá 'a deixa' para Juliana evocar o contexto de uma siderúrgica:

\section{Excerto 4 - Evocando um contexto de siderúrgica}

58 Professora De repente eu realizo de que ela não tá lá... porque eu acho que não dá pra da noite pro dia derrubar uma montanha... pelo que a gente vê em fotos, montanhas de ferro assim... você vê a região sendo... extraída...

59 (?) Que nem formiguinha, né?

60 Professora É, é... é uma coisa lenta... né?... então, agora esse "trem monstro de 5 locomotivas"... eu fiquei curiosa pra saber se é possível ter "trem de 5 locomotivas"...mas aí é uma coisa que exige uma pesquisa..

61 Asdrúbal ( ) 150 vagões de um trem monstro...

62 Professora E se é pra puxar ferro é muito pesado... né?

63 Juliana meu tio trabalhou uma época numa... num lugar que tinha essas coisas... ele trouxe pra gente um ( ) 
desse tamanho assim... que é minério... não é só ferro... que a gente deixou de peso de papel... fica muito bonito... ficou rústico... mas de pegar na mão deve pesar uns 2 quilos...

64 Professora Nossa!

65 Juliana Aquela coisa minúscula...

66 Professora Nossa!

67 Juliana quando você pega aquilo é um

68 (?)

69 Juliana

70 Professora

71 Juliana

72 Professora

Nossa... não imaginei...

É muito denso...

Interessante... eu não imaginei que fosse tão pesado.

\section{É muito pesado...}

Então realmente pode ser que precise mesmo... e a Vale tem os trens dela... né?... pra... pra transportar os minérios... que os sem terra tão vira e mexe bloqueando a... a linha de trem... né?... tem... já li esse ano pelo menos umas duas vezes no jornal que eles fizeram isso e atrapalha... deixa um dia parado lá...

Assim, no turno 62, Juliana evoca o contexto de uma siderúrgica, onde trabalhava um tio e onde ela teve a oportunidade de obter conhecimentos sobre o contexto de metalurgia do ferro e do aço, que vão possibilitar uma melhor compreensão do contexto de mineração em Itabira, assim como a construção de uma leitura metafórica no excerto 7. No excerto 4, ela enfatiza o peso do ferro, que é um argumento para justificar que 0 trem seja muito grande. Compreendendo a intenção da argumentação da aluna, a professora conclui que realmente o trem precisa ser muito grande e comenta que a Companhia Vale do Rio Doce 'tem os trens dela para transportar os minérios'. Nossa pesquisa posterior confirmou a informação de que a Vale é que opera na região desde 1942, quando começou a extração no Pico do Cauê, que se transformou na Montanha Pulverizada (cf. ZANOTTO, 2010).

No excerto 5 a seguir, Juliana inicia dizendo que esse poema não é tão complicado 'perto do arquivado'. Ela está se referindo, metonimicamente (METÁFORA PELO POEMA, OU PARTE PELO TODO), ao poema "Amor e seu Tempo", de Drummond de Andrade (1998, p.42), que possui metáforas enigmáticas, dentre elas a do 'arquivar', que foi muito discutida pelo grupo em outra vivência na disciplina. Juliana termina sua fala mencionando o

'finalzinho' como sendo ainda um problema a ser resolvido. A professora concorda e começa a dizer que esse finalzinho merece um pouco mais de atenção, com o intuito de que o grupo se concentre finalmente nesses versos finais, mas parece que falta resolver melhor a questão do 'acordo e não a encontro'. Assim, Eulália leva a discussão para esses versos novamente no turno 77 :

\section{Excerto 5 - Personificação da montanha}

75 Juliana

assim... quando... a primeira vez que li o poema... eu achei simples perto do arquivado e de outros poemas ele não é tão complicado... né?... agora, nesse finalzinho...

76 Professora É... o finalzinho.... "foge minha serra, vai deixando no meu corpo a paisagem - mísero pó de ferro, e este não passa" esse eu acho que merece um pouco mais de...

77 Eulália O outro grupo deu problema o não a encontro... como o título é que apresenta a montanha... se você tira o título e lê só não a encontro ele provoca outras leituras... né?

78 Professora É...

79 Nete Esse "não a encontro"...

80 Professora Mas pra mim mesmo com o título... parece que ele tá falando de uma mulher, né?... esta manhã acordo e não a encontro... a gente vê muito aquelas cenas de filme que o cara passa a noite e de repente acorda e que de... né?

81 Asdrubal

é mas... será que ele não colocou também... quero dizer... talvez essa relação que ele tinha com a montanha?... relação de alguém que ele gostava... de uma coisa ( ) essa é a leitura que a professora fez, que a professora fez na... na vivência... não foi?... eu lembro que você falou dessa relação íntima que ele tinha com a montanha...

82 Professora É... eu nem lembrava que eu tinha falado... eu acho também que... hã... eu acho também que dá uma idéia dessa relação afetiva sim... E de uma certa personificação da... "foge minha serra"... é... "foge minha amada"... a gente pode pensar assim...

Eulália lembra que no outro grupo do qual ela participou, os versos que provocaram maior discussão foram os iniciais: Esta manhã acordo e não a encontro. Ela diz que se tirasse o título, o não a encontro provocaria outras leituras, mas a professora discorda dizendo que, mesmo com o título, a primeira ideia que vem ao leitor é de uma mulher. A professora admite que quando leu pela primeira vez, a primeira 
ideia que veio foi da mulher amada. Muitos leitores fizeram essa leitura top-down em outros grupos e depois a reformularam ao ler o restante do poema. Entretanto, Asdrúbal, lembrando-se também da outra vivência, afirma que a professora disse que essa maneira de dizer sugeria a 'relação íntima que ele tinha com a montanha'. A professora confirma que esses versos dão ideia da relação afetiva que Drummond tinha com a montanha. Essa ideia é reforçada pelo verso 'foge minha serra', que evidencia a personificação da montanha, de tal modo que dizer 'foge minha serra' é equivalente a dizer 'foge minha amada'. Assim os dois primeiros versos (esta manhã acordo e/ não a encontro) associados ao 'foge minha serra' sugerem uma relação afetiva com a montanha confirmada pela leitura do poema integral. Essa leitura se confirma também no texto Vila de Utopia, no volume autobiográfico Confissões de Minas. Em suma, o contexto co-textual da poesia e o contexto da obra de Drummond reforçam a relevância dessa leitura.

A interpretação da personificação é importante, porque a relação afetiva com a montanha será a CAUSA para as leituras do 'mísero pó de ferro, e este não passa' como dor pela perda, saudade, que são os EFEITOS, como veremos na segunda parte da análise a seguir.

\subsection{Interpretando o 'finzinho embolado'}

É interessante retomar os excertos analisados em Zanotto (2010) para refletir sobre o papel da metonímia conceptual nas inferências dos dois momentos da compreensão do texto, assim como sobre o papel dos contextos evocados e conhecimentos ativados.

Na primeira parte da análise, os alunos foram guiados por Asdrúbal, Nete e Eulália para os pontos problemáticos do contexto co-textual (CUTTING, 2003) anterior ao 'finzinho embolado', cuja discussão pelo grupo, num raciocínio coletivo, levará à construção de uma cadeia de inferências metonímicas, culminando com uma leitura metafórica. O desempenho de Asdrúbal, Nete e Eulália pode ser

atribuído ao fato de terem participado de outra vivência de leitura do mesmo texto, o que mostra que um texto literário pode precisar de mais de um evento de leitura para poder ser realmente interpretado.

No excerto 6 a seguir, é Asdrúbal novamente quem vai desencadear a discussão, focalizando o verso final 'mísero pó de ferro, e este não passa' e levantando a hipótese: 'não seria assim uma questão...do mal que faz?' (t. 83), guiado pela metonímia CAUSA PELO EFEITO, ou PÓ DE FERRO PELO MAL. Entretanto, é uma leitura metonímica genérica ainda, porque há vários tipos de mal, e o grupo vai raciocinar especificando esse mal, ou dano, em duas direções: danos físicos e danos emocionais. Vejamos:

\section{Excerto 6}

83 Asdrubal

Asdrubal

$86 \quad$ Eulália

$87 \quad$ Asdrubal

88 Professora

89 Asdrubal
Juliana

$\begin{array}{ll}90 & \text { Juliana } \\ 91 & \text { Asdrubal } \\ 92 & \text { Professora }\end{array}$

$93 \quad$ Eulália

94 Juliana
Agora essa passagem "mísero pó de ferro e este não passa"... não seria assim uma questão... do $\underline{\mathrm{mal}}$ que faz?... né?

ah, verdade...

Né, do mal que faz pras pessoas essa extração... essa... o resultado de todo... de toda essa... esse (?). é uma crítica esse mísero pó seria...

O mal que faz pras pessoas... as pessoas acabam inalando aquele pó, né?

ah, você tá pensando na inalação mesmo..

é, que ele fala, ó... "foge minha serra", "vai deixando no meu corpo a paisagem"... aqui ó... eu tou lendo essa a paisagem como se fosse 0 mísero pó de ferro... então vai deixando no meu corpo o mísero pó de ferro e este não passa.. Tipo essas intoxicacões? É!

Cê sabe que eu não tinha pensado nisso?... eu acho que é uma leitura muito possível aí mesmo...

Também... possível...

Aí seria uma crítica bem... Aí seria uma crítica bem... Aí o poema vai pra outro lado, né?... Pega uma coisa bem...

95 Asdrubal não pega só o lado afetivo com a montanha.

96 Professora Dá uma crítica...mas não naquela direção...engraçado quando eu li, Asdrúbal...eu pensei assim 'mísero pó de ferro e este não passa'... eu pensei na dor de ver a montanha destruída que não passava...sabe...mas eu acho que a sua leitura ( ) é muito possível...porque...mas quando fala 
'este não passa'...esse 'passa' leva a dor...viu?...mas eu acho que não passa...assim...ele...cê inalou...as consequências no seu corpo tão lá...eu naõ sei que tipo de consequência tem do ferro...eu nunca ouvi falar...era o caso de...

97 Cíntia Mas da doença que não passa que não vai embora...

98 Professora A doença não vai embora... pode

99 Sócrates A poeira do ferro...a paisagem que fica pra ele que é só esse pó de ferro....

100 Asdrubal E que tá no corpo dele...

101 Professora Mas olha, da outra vez você não leu assim... você vê?... e agora você leu... que interessante... e eu acho que tá fazendo muito sentido, né?... porque realmente a gente inala o pó e então a paisagem fica no corpo dele pelo pó que ele inalou.

Juliana concorda com Asdrúbal (t. 84) e ele continua seu raciocínio dizendo: 'Né, do mal que faz pras pessoas essa extração (t. 85), ou seja, Asdrúbal explicita que a 'extração' do ferro causa um 'mal' para as pessoas. Ele está, portanto, enunciando os frames da interpretação: EXTRAÇÃO DO MINÉRIO e CAUSAR DANO, que vão guiar a interpretação dos versos finais. O raciocínio de Asdrúbal revela "a construção de uma cadeia metonímica, porque a 'extração' é CAUSA do 'pó de ferro', que, por sua vez, será a CAUSA do 'mal' que faz para as pessoas (EFEITO)" (ZANOTTO, 2010, p. 628).

Em seguida, Eulália continua a cadeia metonímica, inferindo a força ilocucionária do 'mísero pó de ferro' como crítica (t. 86), também guiada pela metonímia CAUSA PELO EFEITO. Asdrúbal continua seu raciocínio e explica que está pensando no ' $m a l$ causado pela 'inalação do pó de ferro (t. 87), guiado pela metonímia EFEITO PELA CAUSA. A professora pergunta se ele está pensando na inalação mesmo (t. 88). Ele confirma e, em seguida, explicita seu raciocínio, retomando os versos 'foge minha serra, vai deixando no meu corpo a paisagem' e explicando: 'aqui ó...eu tou lendo essa a paisagem como se fosse o mísero pó de ferro... então vai deixando no meu corpo o mísero pó de ferro e este não passa...' (t. 89). Ele está interpretando a metonímia do poema 'vai deixando no meu corpo a paisagem', como sendo 'vai deixando no meu corpo o pó de ferro', ou seja, parte da paisagem, guiado pela metonímia TODO PELA PARTE, ou PAISAGEM PELO PÓ DE FERRO ${ }^{5}$.

Juliana complementa sua ideia, dizendo ' tipo essas intoxicações?' (t. 90), o que significa que a inalação (CAUSA) causa intoxicação (EFEITO). Ele concorda enfaticamente: 'É!' O pensamento de Asdrúbal, com a colaboração de Juliana e Cíntia, segue um raciocínio do genérico para o específico, para definir o que é esse 'mal', guiado pelas metonímias EFEITO PELA CAUSA / CAUSA PELO EFEITO, resultando na cadeia metonímica:

A extração (CAUSA) provoca um EFEITO - o pó de ferro, que CAUSA um mal (EFEITO), que é causado pela inalação do pó de ferro (CAUSA), que CAUSA intoxicações (EFEITO), que vai CAUSAR uma doença (EFEITO) (ver turno 97).

Nos turnos 92 a 94, a professora diz que não tinha pensado nessa leitura e que a considera possível; Eulália concorda e Juliana volta à ideia da crítica, afirmando que "o poema vai para outro lado". No turno 95, Asdrúbal observa que o poema 'não pega só o lado afetivo com a montanha', como havia sido interpretado no excerto 5 . Ele quer dizer que 'não pega' só os danos emocionais, como vai esclarecer a professora, ao falar da própria leitura: "eu pensei na dor de ver a montanha destruída que não passava" (t. 96). Ler como dor pela perda é um dano emocional para o poeta, pois a montanha amada havia sido destruída. Essa é uma leitura guiada pela metonímia CAUSA PELO EFEITO e pelo frame CAUSAR DANO. No final de sua fala, a professora levanta o problema das consequências do pó de ferro inalado no organismo, mas Cíntia entra complementando a ideia da professora dizendo que se trata da "doença que não passa que não vai embora" (t. 97). Nossa pesquisa posterior confirmou que a inalação do ferro causa uma doença chamada pneumoconiose por intoxicação, que é incurável.

\footnotetext{
${ }^{5} \mathrm{Na}$ verdade, a interpretação de Asdrúbal contém implícitas outras instâncias do esquema imagético parte pelo todo, pois o pó de ferro é parte da montanha, que, por sua vez, é parte da paisagem. Do mesmo modo, o corpo (TODO) está sendo interpretado, na verdade, como pulmão (PARTE) devido à inalação. Estamos considerando a inferência PARTE PELO TODO, ou TODO PELA PARTE, como instanciação do esquema imagético, mas isso será objeto de discussão futura.
} 
Encerrando esse excerto, Sócrates e Asdrúbal sintetizam de forma poética, quando Sócrates diz: "a paisagem que fica pra ele que é só esse pó de ferro..." (t. 99) e Asdrúbal complementa "e que tá no corpo dele!' (t. 100). A professora sintetiza o pensamento deles dizendo: "realmente a gente inala o pó e então a paisagem fica no corpo dele pelo pó que ele inalou" (t. 101).

Em suma, neste excerto eles trabalharam para resolver o enigma constituído pelos três versos finais e chegaram a uma interpretação que resolveu as incongruências desses versos. O grupo estava satisfeito e parecia não haver mais nada, mas Juliana, no excerto 7 , vai dizer que tem algo a mais.

No excerto 7, a professora se dirige a Asdrúbal observando que ele não estava muito interessado no início da vivência, pelo fato de já ter participado de outra, mas, nesta segunda vivência, conseguiu construir uma leitura que solucionou as incongruências dos versos finais.

\section{Excerto 7 - Leitura metafórica}

135 Professora Você viu? (dirigindo-se a Asdrúbal) Você precisa fazer duas vivências pra fazer essa leitura...

136 ??? os coitadinhos do ENEM em 15 minutos com mais não sei quantas mil questões tem que resolver...

137 Asdrúbal Vou ficar quietinho (?) meus colegas. Mas é uma coisa assim... que... tava me incomodando já da outra vez, só que eu não consegui, sabe quando o negócio fica na sua cabeça, mas você não consegue decifrar a leitura assim?... não tava conseguindo decifrar esse trem... porque... não pode ser uma coisa à toa...

138 Professora Faz muito sentido o que você leu, porque vai deixando no meu corpo a paisagem, quer dizer... é lógico, eu tô inalando a paisagem...

139 Juliana

Você sabe, eu tô até pensando que além disso que eu tô inalando a paisagem... eu não consigo não ser o meu passado, né?... eu acho... não tenho bem certeza... vai, eu vou pegar pelo que eu lembrei... mas eu acho... que quando você radiografa a pessoa, fica a árvore do pulmão toda cheia de ferro, forma como se fosse uma árvore, como se fosse uma paisagem...

Ele conseguiu resolver o enigma, mas precisou de duas vivências para isso. Essa afirmação da professora leva um leitor do grupo (não identificado) a dizer: "os coitadinhos do ENEM' em 15 minutos com mais não sei quantas mil questões tem que resolver" (t. 136), E Asdrúbal responde que pretendia ficar quietinho para não atrapalhar os colegas. No entanto, diz que tinha uma 'coisa assim' que o estava incomodando e que tinha ficado na cabeça dele, mas não estava conseguindo decifrar (t. 137). A professora diz que sua leitura 'faz muito sentido', pois "vai deixando no meu corpo a paisagem" quer dizer "eu to inalando a paisagem" (t. 138).

Em seguida, Juliana, aproveitando a deixa da professora, diz que, além do 'eu to inalando a paisagem', tinha algo a mais (t. 139). Mas, antes de dizê-lo, ela observa que "eu não consigo ser o meu passado, né?", referindo-se à experiência que teve na siderúrgica em que o tio trabalhava. E ela acrescenta algo interessante, embora diga que não tem certeza: "mas eu acho... que quando você radiografa a pessoa, fica a árvore do pulmão toda cheia de ferro, forma como se fosse uma árvore, como se fosse uma paisagem..." (t. 139).

Juliana está construindo duas metáforas imagéticas (LAKOFF; TURNER, 1989), ao mapear uma imagem convencional (a árvore) em outra imagem, a da árvore que aparece na radiografia do pulmão, quando diz: "quando você radiografa a pessoa, fica a árvore do pulmão toda cheia de ferro, forma como se fosse uma árvore". Em seguida, ela completa a ideia, construindo outra metáfora imagética: "como se fosse uma paisagem", relacionando a árvore do pulmão com a paisagem. Nessa segunda metáfora, há a combinação com a metonímia PARTE PELO TODO, pois há uma relação de parte pelo todo entre árvore e paisagem, constituindo, assim, uma metaftonímia integrada (GOOSSENS, 2003). As metáforas imagéticas foram construídas a partir da cadeia de leituras metonímicas, constituindo também uma metaftonímia cumulativa. Essas interpretações foram orientadas pelo frame CAUSAR DANO e pelos conhecimentos adquiridos no contexto da siderúrgica, conforme Juliana comenta alguns turnos depois. O mais relevante desses conhecimentos para a construção 
das leituras finais é que "um padre já mostrava as radiografias, então ele [o poeta] viu que aquilo é uma árvore, porque uma vez que ele tá em Minas, ele pode ter visto casos assim" (t. 155).

\section{Considerações finais}

O objetivo deste artigo foi investigar os contextos evocados pelos leitores e os conhecimentos ativados que serviram de base para a construção das inferências metonímicas e metafóricas, assim como o papel da metonímia conceptual como guia inferencial para os leitores.

Em relação aos contextos, um aspecto que chamou nossa atenção, nos excertos analisados na primeira parte, foi que, embora a vivência do Pensar Alto em Grupo seja uma prática social situada, as mentes dos leitores viajaram para outros contextos remotos, além do contexto local. Essa constatação aponta para uma relativização do contexto local, porque a evocação dos contextos remotos foi relevante para trazer conhecimentos que foram fundamentais para a construção dos frames de interpretação da poesia: EXTRAÇÃO DO MINÉRIO e CAUSAR DANO, que estão interligados metonimicamente, constituindo, assim, a metonímia temática do texto. Desse modo, o raciocínio inferencial dos leitores na primeira parte, que teve a metonímia conceptual como guia inferencial em muitos momentos, tornou possível a interpretação mais elaborada dos versos finais, que constituem a parte mais densa do poema. Entretanto, o contexto local não deixou de ter sua importância, pois o fato de os alunos terem vivenciado a prática dialógica e colaborativa de leitura, na disciplina, durante todo o semestre, possibilitou que eles construíssem, de forma dialógica e colaborativa, os sentidos

Em relação à segunda pergunta, os dados constituíram evidência dos diferentes papéis da metonímia conceptual, que funcionou, principalmente, como guia inferencial do contexto situacional de referência do poema, dos frames e da força ilocucionária na primeira parte. $\mathrm{Na}$ segunda parte da análise, as inferências metonímicas possibilitaram a construção de leituras metonímicas para 'resolver' as incongruências da metonímia como figura poética. Esse fato faz emergir uma nova questão: como diferenciar a metonímia como figura e a metonímia como guia inferencial? Essa questão abre novos caminhos para a pesquisa e vamos deixá-la para trabalhos futuros.

\section{Referências}

BAKHTIN, Mikhail. Estética da criação verbal. Trad. Paulo Bezerra. 4. ed. São Paulo: Martins Fontes, 2003.

BARCELONA, Antonio. The role of metonymy in meaning construction at discourse level: A case study. In RADDEN. Günter et al (Eds.). Aspects of meaning construction. Amsterdam: John Benjamins, 2007, p. 51-75.

CAMERON, Lynne. Metaphor in educational discourse. London/New York: Continuum, 2003.

CRESWELL, John W. Projeto de pesquisa: métodos qualitativo, quantitativo e misto. Trad. Magda França Lopes. 3a. ed. Porto Alegre: Artmed, 2010.

DRUMMOND DE ANDRADE, Carlos. Sentimento do Mundo. In: DRUMMOND DE ANDRADE, Carlos. Carlos Drummond de Andrade: obra completa. Org. Afrânio Coutinho. Rio de Janeiro: José Aguilar, 1967. p. 101-102.

DRUMMOND DE ANDRADE, Carlos. Impurezas do Branco. .8ª ed. Rio de Janeiro: Record, 1998.

DRUMMOND DE ANDRADE, Carlos. Confissões de Minas. São Paulo: Cosac Naify, 2011.

ERICKSON, Frederick. Qualitative methods in research on teaching. In: WITTROCK, Merlin C. (Ed.). Handbook of research on teaching. New York: MacMillan, 1986. p. 119-161.

ERICSSON, K. Anders; SIMON, Herbert A. Protocol analysis. Cambridge, MA: MIT Press, 1984.

FAUCONNIER, Gilles. Methods and generalizations. In: JANSSEN, Theo; REDEKER, Gisela (Eds.). Scope and foundations of cognitive linguistics. The Hague: Mouton de Gruyter, 1999. p. 95-127.

GIBBS, Raymond W. Experimental texts of figurative meaning construction. In: RADDEN, Günter et al. (Eds.). Aspects of meaning construction. Amsterdam: John Benjamins, 2007. p. 19-32.

GOOSSENS, Louis. Metaphtonymy: the interaction of metaphor and metonymy in expressions for linguistic action. In: DIRVEN, René; PÖRINGS, Ralf (Eds.). Metaphor and 
metonymy in comparison and contrast. Berlin/New York: Mouton de Gruyter, 2003. p. 349-377.

HILPERT, Martin. Chained metonymies in lexicon and grammar. In: RADDEN, Günter et al. (Eds.). Aspects of meaning construction. Amsterdam: John Benjamins, 2007. p. 77-98.

LAKOFF, George; TURNER, Mark. More than cool reason: A field guide to poetic metaphor. Chicago, London: The University of Chicago Press, 1989.

MOURA, Heronides M. M.; ZANOTTO, Mara Sophia. Investigando teórica e empiricamente a indeterminação da metáfora. Gragoatá, Niterói, v. 26, p. 9-42, 2009.

PANTHER, Klaus-Uwe; THORNBURG, Linda (Eds.). Metonymy and pragmatic inferencing. Amsterdam: John Benjamins, 2003.

RADDEN, Günter et al. (Eds.). Aspects of meaning construction. Amsterdam: John Benjamins, 2007.

STAKE, Robert E. Case studies. In: DENZIN, Norman; LINCOLN, Yvonna S. (Eds.). Strategies of qualitative inquiry. London: Sage, 1998. p. 86-109.

ZANOTTO, Mara Sophia. Metáfora, cognição e ensino de leitura. D.E.L.T.A., São Paulo, v. 11, n. 2, p. 241-254, 1995.

ZANOTTO, Mara Sophia. The multiple readings of 'metaphor' in the classroom: co-construction of inferential chains. D.E.L.T.A., São Paulo, v. 26 , p. 615-644, 2010. Número especial..

ZANOTTO, Mara Sophia. As múltiplas leituras da metáfora: desenhando uma metodologia de investigação. Signo, Santa Cruz do Sul, v. 39, n. 67 , p. 3-17, 2014.

ZANOTTO, Mara Sophia; MOURA, Heronides M. M. Indeterminacy and negotiation. In: VERSCHUEREN, Jef et al. (Ed.). Handbook of pragmatics. Amsterdam/Philadelphia: John Benjamins, 2000. p. 1-13.

ZANOTTO, Mara Sophia; PALMA, Dieli V. Opening Pandora's box: multiple readings of a 'metaphor'. In: ZANOTTO, Mara Sophia; CAMERON, Lynne; CAVALCANTI, Marilda (Ed.). Confronting metaphor is use: an applied linguistic approach. Amsterdam: John Benjamins, 2008. p. 11-43. 